\title{
THE ANEURINPYROPHOSPHATE CONTENT OF RED AND WHITE BLOOD CORPUSCLES IN THE RAT AND IN MAN, IN VARIOUS STATES OF ANEURIN PROVISION AND IN DISEASE*
}

\author{
by \\ G. SUITS \\ Central Institute for Nutrition Research T.N.O., Utrecht (Netherlands) \\ and \\ E. FLORIJN \\ Laboratory for Physiological Chemistry, The University, Utrecht (Netherlands)
}

This work has originated with the problem which method could serve best to detect slight aneurin deficiencies"* and to exclude the diagnosis: aneurin deficiency in patients with symptoms, resembling those of, but not caused by this disease.

Although it is not yet possible to correlate the tissue aneurin level with the optimum tissue function of aneurin the most reliable method would still be the determination of aneurin or better aneurinpyrophosphate in the patient's tissues. As this is also utterly impossible we are left with two possibilities, viz., the investigation of urine (aneurin) or blood (aneurin, aneurinpyrophosphate (APP) or pyruvic acid).

\section{Urine}

Most work has been done on urine. Yet many difficulties are encountered when drawing conclusions concerning the aneurin provision of the body from the aneurin content of the urine. There is no conclusive evidence that a small amount of aneurin excreted indicates the presence of a low amount of aneurin in the tissues, whether aneurin is determined in urine passed during 24 hours or in urine excreted during the night (fasting excretion). And though pronounced states' of aneurin deficiency are indicated by absence of a significant aneurin excretion after a single oral dose of 5 or $\mathrm{io}$ mg of aneurin, no quantitative relation appears to exist between the excretion under these conditions and the aneurin provision of the body when the latter is adequate or only slightly below par.

For example, the aneurin excretion in urine suddenly drops to a much lower level upon switching from an adequate diet to a diet low in aneurin, but then remains prac-

* This work forms part of the investigations on aneurin metabolism by H. G. K. WESTENBRINK and collaborators.

** We term "aneurin deficiency" a condition in which the cells of the body--as a whole or in part-do not operate as well as could be possible. We do not know the level of aneurin supply required for this optimal condition. Therefore we are forced, for the time being, to compare with normal. well-fed healthy individuals, living under the same cirtumstances, except for the difference in aneurin supply.

References $p .64$. 
tically constant for a considerable time, though the body must become depleted of aneurin in the course of this period. Mason AND Williams ${ }^{1}$, e.g., observed that after living for 5 months on a diet low in aneurin the excretion of this substance was not lower than as had been found after living on the same diet for 4 weeks only. It seems that the amount of aneurin excreted more likely indicates the aneurin content of the food ingested than the degree of saturation of the tissues.

Another difficulty in drawing conclusions concerning an individual is formed by the very large variations observed in numerous determinations in subjects living under equal nutritional conditions. MICKELSEN, CASTER, AND KEYS ${ }^{2}$ prefer the determination of pyramine, a product of aneurin breakdown, as in individuals on the same diet the excretion of this substance does not show these great variations. But it has not been proved that a correlation exists between pyramine excretion and aneurin content of the tissues. Possibly also the pyramine excretion only reflects the aneurin content of the food digested previous to the determination.

\section{Blood}

Aneurin forms part of the prosthetic group of various enzymes catalysing intermediate reactions in carbohydrate metabolism. Hence it is to be expected that intermediate products of carbohydrate metabolism will accumulate in tissues and blood of aneurin-deficient animals and men. As most of these enzymes pertain to the various paths along which pyruvic acid may be metabolized many investigations have been carried out on the pyruvic acid content of the blood. As a matter of fact this appeared to be increased in aneurin deficiency but the differences are too small to make certain the diagnosis: aneurin deficiency from a few measurements of this acid only ${ }^{3}$. Moreover an increase of the bisulphite binding substances in blood was also found in other diseases (febrile diseases, hart disease, etc., ${ }^{5}$ ).

We believe that determinations of APP in blood are to be preferred for detecting aneurin deficiencies. However, the directions given below should not be neglected. The determination of APP in blood is of little value without an accurate count of the blood cells and a study of the blood picture.

Several workers have determined total aneurin or APP in blood, but the wide range of variability makes it difficult to draw conclusions regarding an individual's aneurin provision. We do not exactly know the content of free aneurin of blood, but it must surely be very small as compared to the content of APP, the form in which aneurin is chiefly present in all animal tissues. For this reason the results of the determination of total aneurin are directly comparable with the results of APP determination. Table I gives a survey of the results obtained with several human subjects. The rather broad range in which the values lie, obtained by the same method, will at least partly be caused by variation in the number of blood corpuscles. For APP is only present in the formed elements. The significance of this point has been insufficiently realized by most workers in this field, as only few efforts have been made to establish a positive correlation between APP content and number of white and red cells of the blood. Only a rough estimate exists even of the ratio of the amounts of APP in red and white cells. The investigations of GoodharT and SincLair ${ }^{19}$ and GorHam AND ABELS $^{20}$ only, carried out with methods which are rather inaccurate in our opinion, have shown that the average leucocyte must contain several hundred times as much APP as the average erythrocyte. 


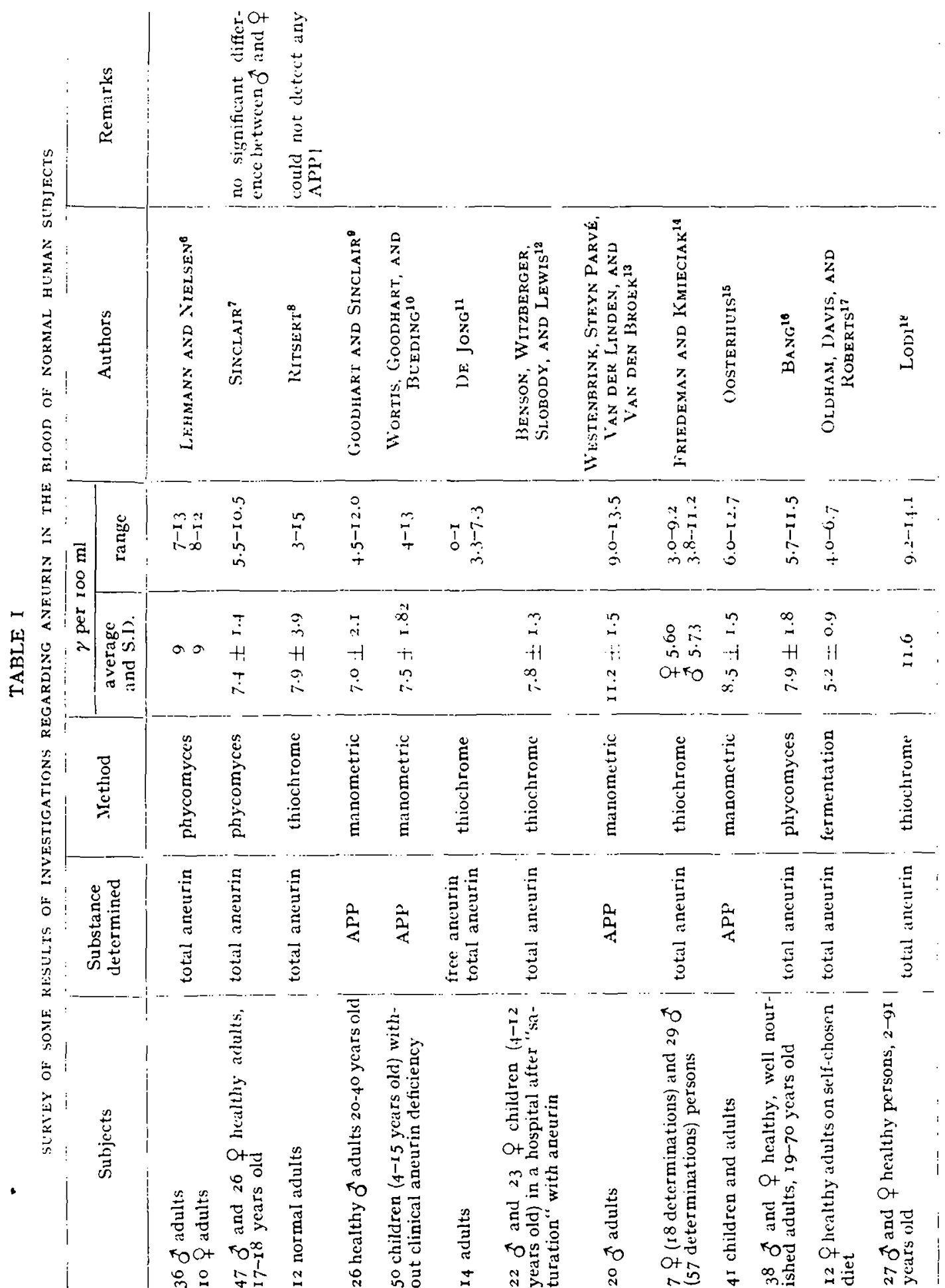


The work described in this paper comprises the exact determination of APP in the erythrocytes and leucocytes of the rat and man, the study of the influence of aneurindeficient diets on the APP contents of these cells and a study of the APP content of total blood and the separate cells in various diseases.

The platelets were not examined thoroughly. The amount of APP they contain must be very small, as this substance could not be detected in plasma obtained by centrifuging for Io min at 3000 r.p.m., in which most of the platelets are still present. Nor did we try to separate the various kinds of leucocytes.

Hence the values given below for the leucocytes pertain to the average white cell. The same holds for the erythrocytes in different stages of development. We were only able to give a separate figure for nucleated red cells as distinct from all erythrocytes of later stages of development taken together.

After some preliminary attempts we abandoned the plan for a complete separation of the red and white corpuscles. After centrifuging the blood for a long time at a high rate the white cells form a tough mass which cannot be resuspended, so that it is impossible to count them. Therefore we proceeded to centrifuging at low rates for long periods of time. In this manner the red and white cells are not completely separated, but then two fractions could be obtained, one containing most of the erythrocytes and very few leucocytes and a second one containing many leucocytes and relatively few erythrocytes. It was possible to perform an accurate count in both fractions. These fractions were resuspended in plasma. By determining their APP content and the APP content of the total blood, and by counting the red and white cells in the obtained cell fractions and in the total blood three equations with two unknowns could now be drawn up, viz.:

$$
\left.\begin{array}{ll}
\text { Total blood: } & a_{1} x+b_{1} y=c_{1} \\
\text { Erythr. fraction: } & a_{2} x+b_{2} y=c_{2} \\
\text { Leuc. fraction: } & a_{3} x+b_{3} y=c_{3}
\end{array}\right\}
$$

Herein $a_{1}, a_{2}$ and $a_{3}$ represent the number of erythrocytes, expressed in $10^{11}$ per $100 \mathrm{ml}$ $\left(10^{6}\right.$ per $\left.\mu \mathrm{l}\right), b_{1}, b_{2}$, and $b_{3}$ the number of leucocytes, expressed in ${ }^{1} 10^{11}$ per $100 \mathrm{ml}$ $\left({ }^{\circ} 0^{6}\right.$ per $\mu \mathrm{l}$ ) and $\mathrm{c}_{1}, \mathrm{c}_{2}$ and $\mathrm{c}_{3}$ the APP content, expressed in $\gamma$ per Ioo $\mathrm{ml}$, in total blood, erythrocyte fraction and leucocyte fraction respectively.

$\mathrm{x}$ and $\mathrm{y}$ are the APP contents of erythrocytes and leucocytes respectively, expressed in $\gamma$ per ${ }^{11}$ cells.

As the number of equations surpasses the number of unknowns, we cannot only determine the best values for $\mathrm{x}$ and $\mathrm{y}$, but also their accuracy*.

To this end the three equations must first of all be brought to equal precision. The inaccuracy of the coefficients $a_{n}$ and $b_{n}$ results from the errors adhering to the counting. Of these the irregular distribution of the cells in the counting chamber is the prevailing source of errors. If the counting is carried out as described below this error of distribution does not exceed that which can be theoretically calculated according to PoIsson.

In this case the following applies:

$$
\text { Standard deviation (S.D.) }=\sqrt{\text { number of cells counted. }}
$$

The coefficients $\mathrm{c}_{\mathrm{n}}$ were obtained by determining the APP contents according to

*For the theoretical basis of the following calculations consult e.g., E. CzuBer, Wahrscheinlich keitsrechnung I. Verlag B. G. Teubner, Leipzig und Berlin, I908, 2e Auflage, \$ I 57 and following. We wish to thank Prof. Dr. M. G. I. Minnaerr for drawing our attention to this method.

References p. 64 . 
WeStEnBRINK et al. ${ }^{13}$. Estimations were at least performed in duplicate. The effect of an APP solution of unknown concentration is compared to that of a number of solutions of known content. From the latter values a standard curve is construed. This curve cannot always be drawn with the same measure of accuracy, so determinations of one series may be more reliable than those of another series, although this difference cannot be expressed in a figure. Experience gathered with a large number of estimations shows that the S.D. of values obtained by determination in duplicate is about $3 \%$.

The S.D.'s of the coefficients of one equation now being known, and the provisional solutions of $\mathrm{X}$ and $\mathrm{Y}$ being simple to estimate from the set of equations, we can calculate the S.D. of each equation $\left(\sigma_{n}\right)$ :

$$
\sigma_{\mathrm{n}}^{2}=\left(\sigma_{\mathrm{a}_{\mathrm{n}}} \mathrm{X}\right)^{2}+\left(\sigma_{\mathrm{b}_{\mathrm{n}}} \mathrm{Y}\right)^{2}+\sigma_{\mathrm{c}_{\mathrm{n}}}^{2}
$$

$\sigma_{a_{\mathfrak{n}}}$ being the S.D. of $a_{n}$, etc.

The three equations ( $I$ ) can now be brought to equal precision by dividing the coefficients by the S.D. of the corresponding equation. We then obtain:

$$
\left.\begin{array}{l}
A_{1} x+B_{1} y-C_{1}=0 \\
A_{2} x+B_{2} y-C_{2}=0 \\
A_{3} x+B_{3} y-C_{3}=0
\end{array}\right\}
$$

in which $A_{n}=z_{n} / \sigma_{n}$, etc.

From these equations the normal equations can be derived:

$$
\begin{gathered}
\left(A_{1}^{2}+A_{2}^{2}+A_{3}^{2}\right) x+\left(A_{1} B_{1}+A_{2} B_{2}+A_{3} B_{3}\right) y-\left(A_{1} C_{1}+A_{2} C_{2}+A_{3} C_{3}\right)=0 \\
\left(A_{1} B_{1}+A_{2} B_{2}+A_{3} B_{3}\right) x+\left(B_{1}^{2}+B_{2}^{2}+B_{3}^{2}\right) y-\left(B_{1} C_{1}+B_{2} C_{2}+B_{3} C_{3}\right)=0 \\
x \sum A_{n}^{2}+y \sum A_{n 1} B_{n}-\sum A_{n} C_{n}=0 \\
x \sum A_{n} B_{n}+y \sum B_{n}^{2}-\sum B_{n} C_{n}=0
\end{gathered}
$$$$
\text { or: }
$$

These last two equations are solved. The solutions $x_{b}$ and $y_{b}$ are the best values appertaining to equations $(\mathrm{I})$. When these values $\mathrm{x}_{\mathrm{b}}$ and $\mathrm{y}_{\mathrm{b}}$ are substituted in equations $(2)$, the left members are generally $\neq 0$. Let the values of these members be $\lambda_{1}, \lambda_{2}$ and $\lambda_{3}$ respectively. If no errors have been made in the calculation, then

$$
\sum A_{n} \lambda_{n}=0 \text { and } \sum B_{n} \lambda_{n}=0
$$

To estimate the accuracy of $x_{b}$ and $y_{b}$, we now calculate $\mu_{,} \mu_{x}$ and $\mu_{y}$ :

$$
\mu=\sqrt{\bar{\lambda}_{1}^{2}+\bar{\lambda}_{2}^{2}+\bar{\lambda}_{3}^{2}}
$$

$\mu_{x}$ and $\mu_{y}$ are solved from the following two sets of equations:

$$
\begin{cases}\mu_{x}^{2} \sum A_{n}^{2}+p \sum A_{n} B_{n}-I=0 & q \sum A_{n}^{2}+\mu_{y} \sum A_{n} B_{n}=0 \\ \mu_{x}^{2} \sum A_{n} B_{n}+p \sum B_{n}^{2}=0 & q \sum A_{n} B_{n}+\mu_{y} \sum B_{n}^{2}-I=0\end{cases}
$$

Now the S.D. of $\mathrm{x}_{\mathrm{b}}$ is: $\sigma_{\mathrm{x}_{\mathrm{b}}}=\mu . \mu_{\mathrm{x}}$ and the S.D. of $y_{b}$ is: $\quad \sigma_{y_{b}}=\mu \cdot \mu_{y}$. 
METHODS

\section{Separation of red and white cells}

A suitable portion of the blood sample to be examined was centrifuged (of rat blood about $5 \mathrm{ml}$, of human blood 15 to $35 \mathrm{ml}$ ). Rat blood was centrifuged in a tube, $15 \mathrm{~cm}$ long and with a volume of about $5 \mathrm{ml}$, human blood in a constricted tube (Fig. I).

The best separation of erythrocytes and leucocytes by centrifuging is obtained if the speed is gradually increased: e.g., $1 / 2-I$ hour at 500 r.p.m., followed by $1 / 2-I$ hour at 1000 r.p.m. and finally $1 / 2-I$ hour at I 500 r.p.m. Sharper centrifuging harbours the risk that the leucocytes become so tightly packed that they cannot be resuspended homogeneously again.

When a constricted tube is used, the cell boundary must be situated at an adequate level in the narrow part of the tube. To achieve this the cell volume must previously be measured with the haematocrit and from this the amount of blood to be centrifuged can be calculated.

The best separation possible of red and white cells having thus been obtained, most of the plasma is drawn off with a pipette and the wide top part of the constricted tube is cut off. Close under the boundary between white and red blood cells a scratch is made on the glass and the tube is made to crack at this level with the aid of a drop of molten glass. Meanwhile the upper aperture of the tube is kept closed with a finger, so the top part of the tube can be removed with its contents. The white cells thus obtained, mixed with relatively few red cells, are transferred to a calibrated tube and diluted to a suitable volume with the corresponding plasma (leucocyte fraction). From the bottom of the lower part of the centrifuge tube a few $\mathrm{ml}$ of red cells are drawn off with a pipette, transferred to another calibrated tube and brought to adequate volume with the same plasma. This is the erythrocyte fraction.

In the total blood and the fractions thus obtained the number of red and white cells per unit of volume is now counted. This must be done with the greatest accuracy. To this end we used the method of

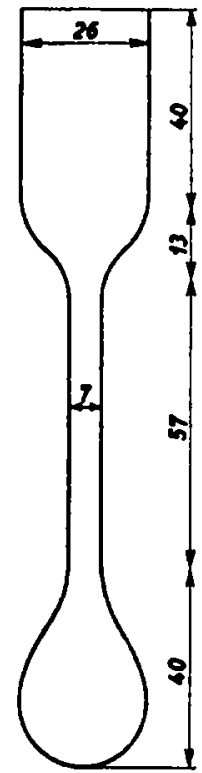

Fig. r. Tube for the separation of erythrocytes and leucocytes in human blood (measurements in $\mathrm{mm}$ ) counting as improved by us. The APP content of the three samples is determined with the manometric method of WESTENBRINK et al. ${ }^{13}$.

\section{Counting the cells}

The counting chamber of BÜRKER-TüRK was used. According to the method in general use the blood is diluted and then simply drawn into the space between coverglass and base by capillary forces. But we observed that the results obtained with one blood sample varied considerably according to whether the count was taken in places in the lattice, more or less distant from the side from which the chamber was filled. This impression, at first still vague, could be confirmed by taking microphotographs of the blood in the four corners of the lattice, as shown in Fig. 2. On the photographs such a large portion of the surface was taken for the count that the unavoidable distribution error of the cells would not be disturbing.

The differences were even larger when surfaces situated far outside the lattice were References $p$. 64 . 
chosen for counting in this photographical manner. This is demonstrated in Fig. 3 . Without exception the number of cells found in positions $A$ and $B$ was much higher
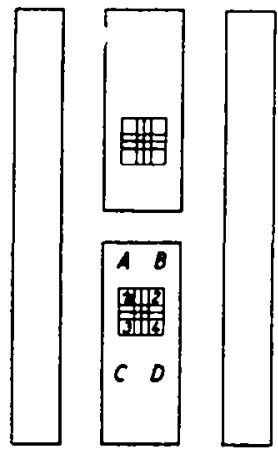

Fig. 3. Schematic drawing of the counting chamber

than that in positions $\mathrm{C}$ and $\mathrm{D}$. Owing to some surface- or capillary effect the front of the drop that is drawn into the chamber apparently contains more cells. After having established that such a disturbing effect is very much in evidence when $0 . I \mu$ of blood is brought onto a slide by

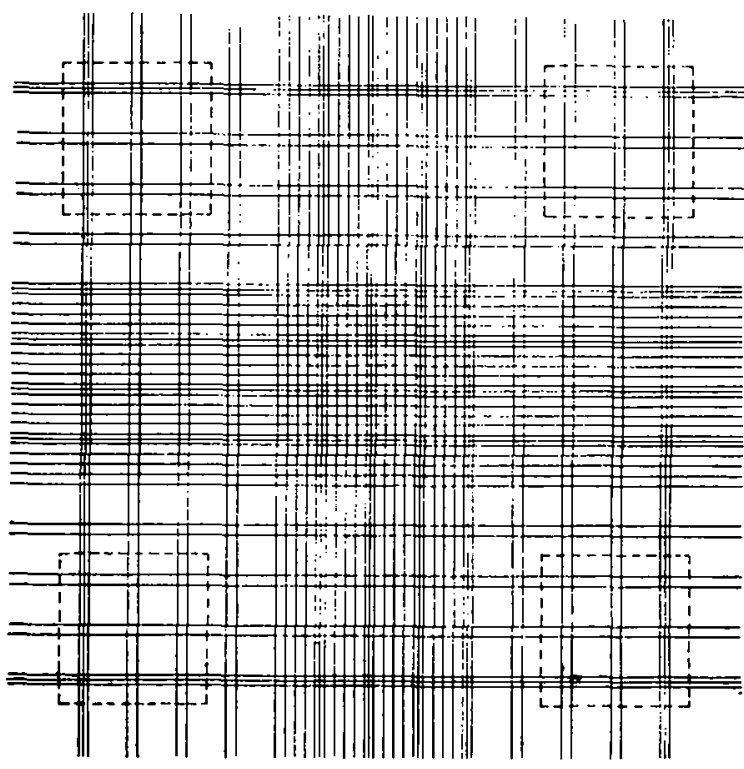

Fig. 2. The lattice in a counting chamber according to BÜRKER-TüRK. Photographs were taken of each of the regions situated in the four corners of the lattice, as indicated by the dotted lines.

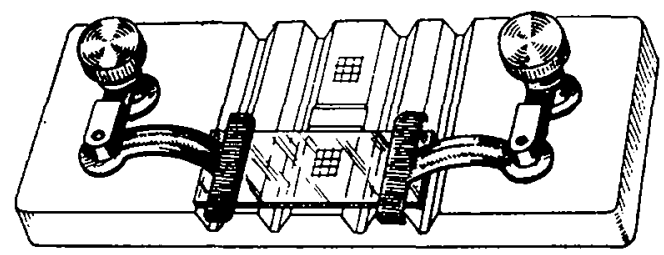

lig. 4. Counting chamber as used when filling according to the "suction method". The coverglass, part of a slide, covers one half of the counting chamber, the clamps press this coverglass evenly on the chamber with the aid of a small cross beam. means of a micropipette according to LINDERSTRøm-LANG and then completely counted, we arrived at the following satisfactory procedure for use with the BürKERTüRK chamber.

After diluting blood in the ordinary manner it is drawn into the counting chamber in a continuous stream. The ordinary cover-glass, covering the whole centre of the base, is excharged for a cover-glass that only covers half of this area. This necessitates a small change in the clamps of the apparatus, as shown in Fig. 4.

On one side of the coverglass the blood flows in from the pipette and on the other side it is absorbed by a slip of filter paper (see Fig. 5). When the blood has risen over a distance of $\mathrm{I} \mathrm{cm}$ in the paper, the supply is stopped and the paper is applied a few seconds

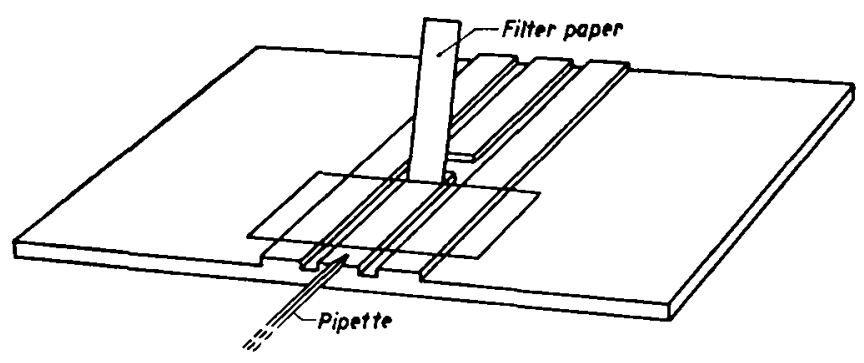

Fig. 5. Schematic diagram of the "suction method" References $p .64$. 
longer until a drop of equal size is left on both sides. Thereupon the filter paper is removed. When proceeding in this manner the cells are distributed over the whole surface according to Porsson's Law.

Some experience is required in choosing a suitable filter paper. It should not be too "hairy" and must be neither too slow nor too rapid in absorbing the fluid. It is also important to know that absorption should not be continued until no blood is left at the other side. For then the results become irregular.

This method has been described more in detail in the Nederland. Tijdschr. Geneesk. ${ }^{21}$. In that paper all figures relating to the comparison of our method with the usual method for filling the counting chamber can also be found.

Comparison of the APP content of red and white blood cells and of some organs of rats on a normal diet and of the same after receiving an aneurin-deficient diet for 5 days

This section comprises a description of the determination of the APP content of red and white blood corpuscles of adult white rats on an adequate diet, and of rats on the same diet followed by 5 , respectively $\mathrm{I}_{4}$ days on a practically aneurin-free diet. APP determinations were also carried out in liver, kidney, muscle and brain of these animals in order to see if a correlation exists between the APP content of the blood cells and that of the tissues on each of the diets.

The adequate diet was composed as follows: Two parts whole wheat flour, one part skim milk powder and $3 \%$ butter. With this diet, rich in aneurin, the rats comsumed several times ro $\gamma$ of aneurin daily.

The aneurin-deficient diet was composed as follows:

$200 \mathrm{~g}$ powdered brewers' yeast, heated to $115^{\circ} \mathrm{C}$ for 5 hours;

$200 \mathrm{~g}$ casein, freed of most of the aneurin;

$4^{\circ} \mathrm{g}$ cod liver oil;

$1400 \mathrm{~g}$ powdered washed polished rice;

$100 \mathrm{~g}$ butter fat;

$60 \mathrm{~g}$ salt mixture.

The aneurin content was about $2 \gamma$ per $100 \mathrm{~g}$, so each rat received about $0.2 \gamma$ daily.

Under aether anaesthesia the abdominal cavity of the rat was opened and 6 to $10 \mathrm{ml}$ blood could be obtained by inserting a glass canula into the aorta. This blood was collected in a tube containing about $30 \mathrm{mg}$ of sodium oxalate. It was then examined in the manner described above. Meanwhile liver, kidneys, brain and leg muscle were isolated and minced with scissors on a watch-glass. About $500 \mathrm{mg}$ of the brei were accurately weighed into a centrifuge tube bearing a mark at $4 \mathrm{ml}$. All determinations were carried out in duplicate. $3 \mathrm{ml}$ of $0.09 \mathrm{n} \mathrm{HCl}$ were added and the mixture was boiled during one minute over a small flame, stirring continuously (the $\mathrm{p}_{\boldsymbol{H}}$ should be between 2.5 and 3.0 ). Immediately afterwards $0.23 \mathrm{ml} \mathrm{x.I6} \mathrm{n}(6.5 \%) \mathrm{KOH}$ were added from a microburette and the volume made up to $4 \mathrm{ml}$ with distilled water. Upon centrifuging a clear extract was obtained, which was diluted with o.I mol phosphate buffer of $p_{\mathrm{H}} 6.5$ to a concentration, suitable for determination of APP according to the manometric method.

In Table II the results thus obtained are summarized.

In Table III we have given the correlation coefficients of the APP contents of red and white cells respectively and the contents of each of the organs examined.

By calculating the corresponding $z$-values (Table IV; see FISHER ${ }^{22}$, p. Ig8) we can decide which correlations show significant differences. In that case the difference be- 
RESULTS OF COUNTS AND DETERMINATIONS OF APP CONTFNTS OF RED AND WHTT:

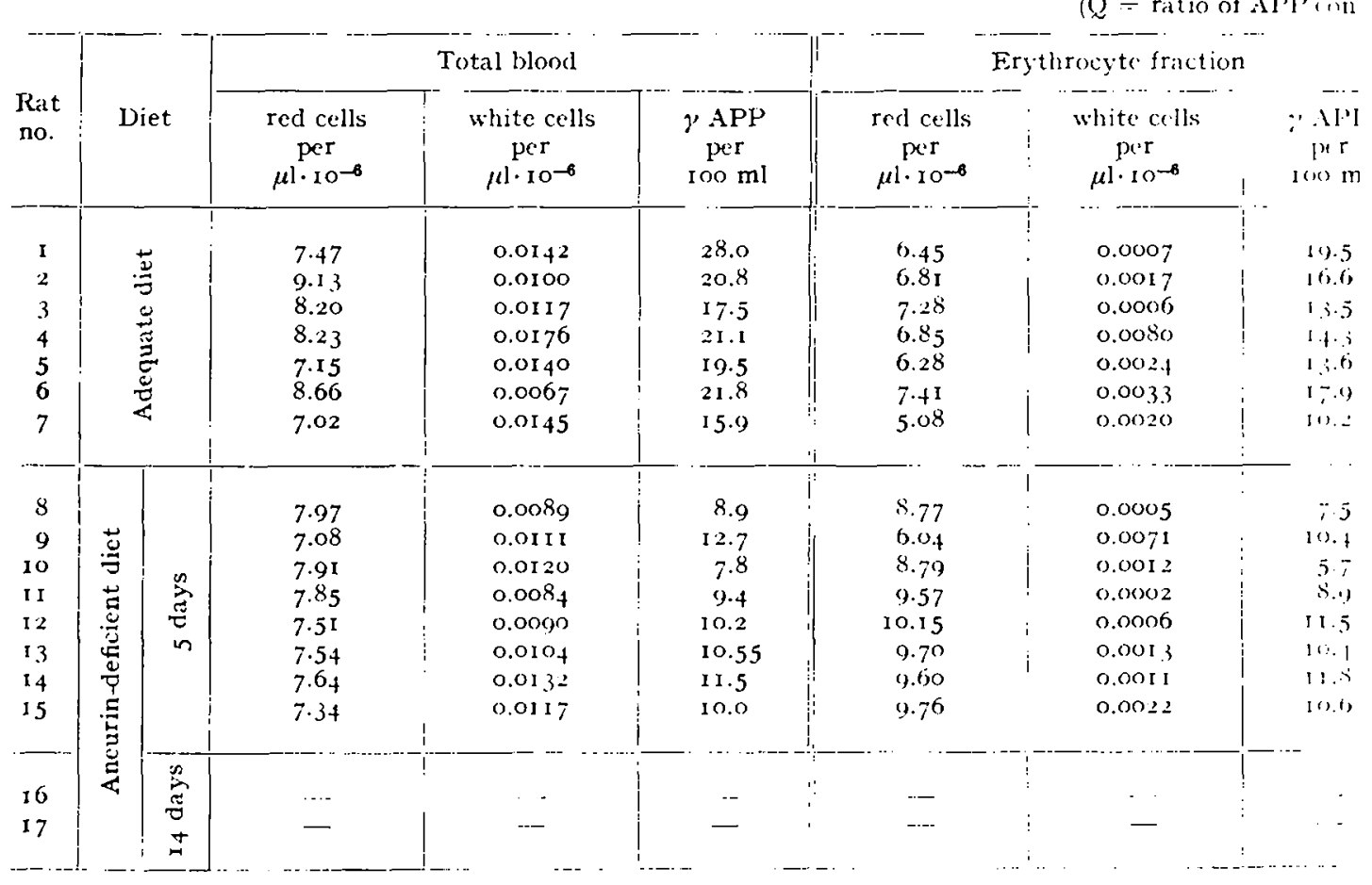

TABLF III

CORRELATION COEFFICIENTS OF APP CONTENTS OF BLOOD CELI.S AND OF VARIOUS ORGANS

\begin{tabular}{l|c|c|c|c} 
& Liver & Kidney & Leg-muscle & Brain \\
\hline Red cells. & 0.93 & 0.98 & 0.93 & 0.67 \\
White cells. & 0.74 & 0.63 & 0.72 & 0.89 \\
\hline
\end{tabular}

TABLE IV

Z-VALUES, CALCULATED FROM THF CORRELATION COFFFICIENTS OF TABLE III

\begin{tabular}{|c|c|c|c|c|}
\hline & Liver & Kidney & Leg-muscle & Brain \\
\hline Red cells. . & I.66 & 2.30 & 1.60 & $0 . S_{1}$ \\
\hline White cells. & 0.95 & 0.74 & 0.91 & $1 .+2$ \\
\hline
\end{tabular}

tween the corresponding $z$-values should be at least 0.85 . This holds in the following instances:

APP contents of: I. erythrocytes and kidney vs., leucocytes and kidney;

2. erythrocytes and liver vs., erythrocytes and brain;

3. erythrocytes and kidney $v$ s., erythrocytes and brain;

4. erythrocytes and muscle $v s .$, erythrocytes and brain.

References p. 64 . 
JGETHER WITH THE APP CONTENTS OF SOME ORGANS OF RATS LIVING ON VARIOUS DIETS f a white and a red cell)

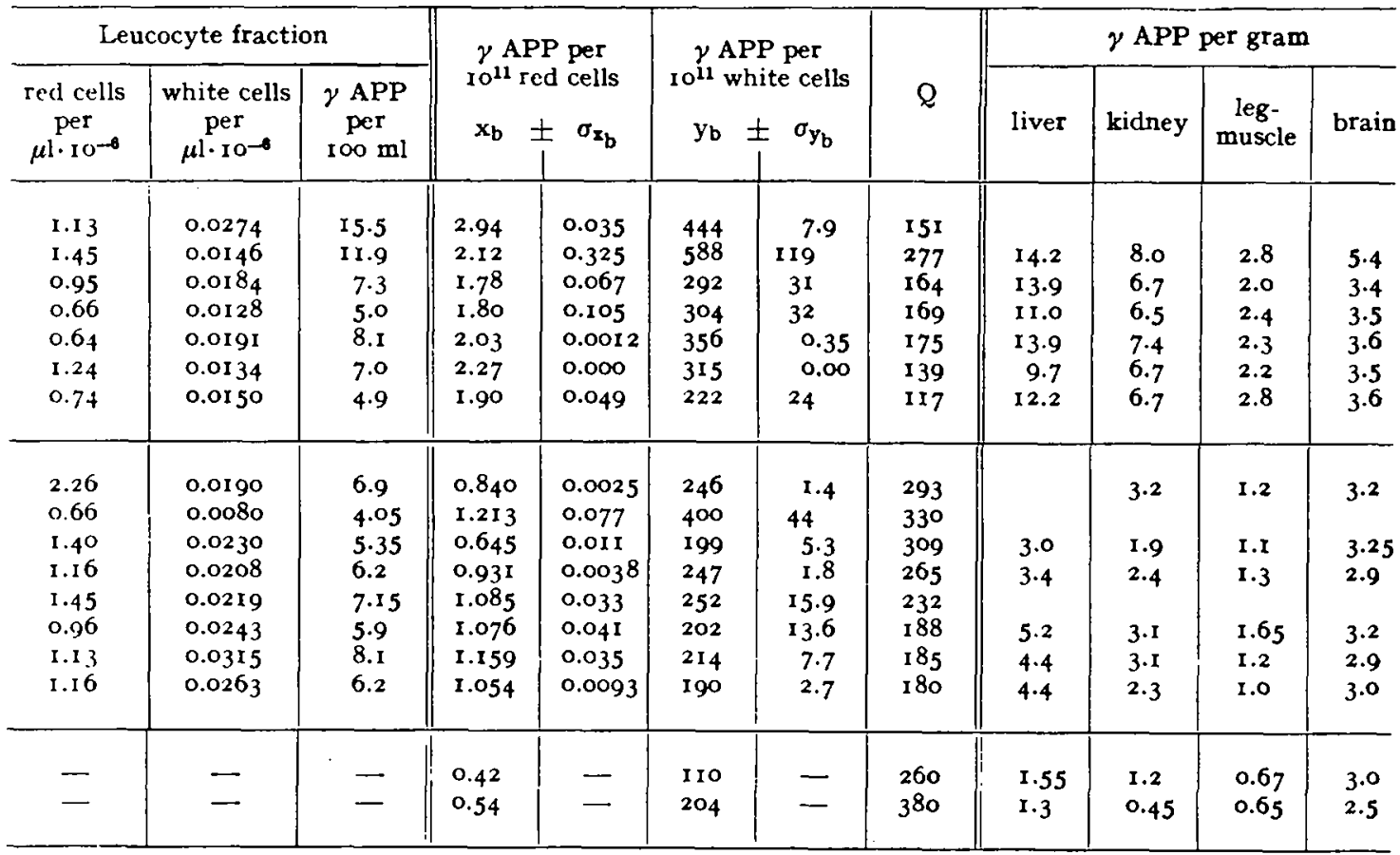

From this we may conclude that, in case of the rat, significantly closer relations, regarding APP contents, exist between red cells and kidney, as compared to white cells and kidney. Also, relations between red cells and liver, kidney or muscle are significantly closer than between red cells and brain. Or (more boldly): regarding kidney red and white cells differ principally, and regarding red cells liver, kidney and muscle differ principally from brain.

Mean values of $A P P$ contents of red and white blood cells of rats on adequate diets and after 5 days on a diet low in aneurin

As has already been mentioned, the accuracy of each calculated APP content of red and white cells could be ascertained. This accuracy is rather variable, so it is not correct to regard the arithmetical mean as a good statistic. Values determined with greater accuracy should bear more weight in calculating the mean than values that are less accurately established.

In Table $\mathrm{V}$ an example has been given of one of our calculations of the best mean.

When $\sigma_{t}=$ standard deviation as a measure for the scattering of the calculated APP contents around their arithmetical mean,

$$
\begin{aligned}
& \sigma_{\mathrm{e}}=\text { standard deviation as a result of experimental inaccuracy, } \\
& \sigma_{\mathrm{ph}}=\text { standard deviation as a measure for the physiological scattering, }
\end{aligned}
$$
then $\sigma_{\mathrm{ph}}^{2}=\sigma_{\mathrm{t}}^{2}-\sigma_{\mathrm{e}}^{2}$.

$$
\sigma_{\mathrm{p}}^{2} \text { is calculated in column } 4: \sigma_{\mathrm{e}}^{2}=\frac{\sum \sigma_{e_{\mathrm{n}}}^{2}}{\mathrm{n}}
$$




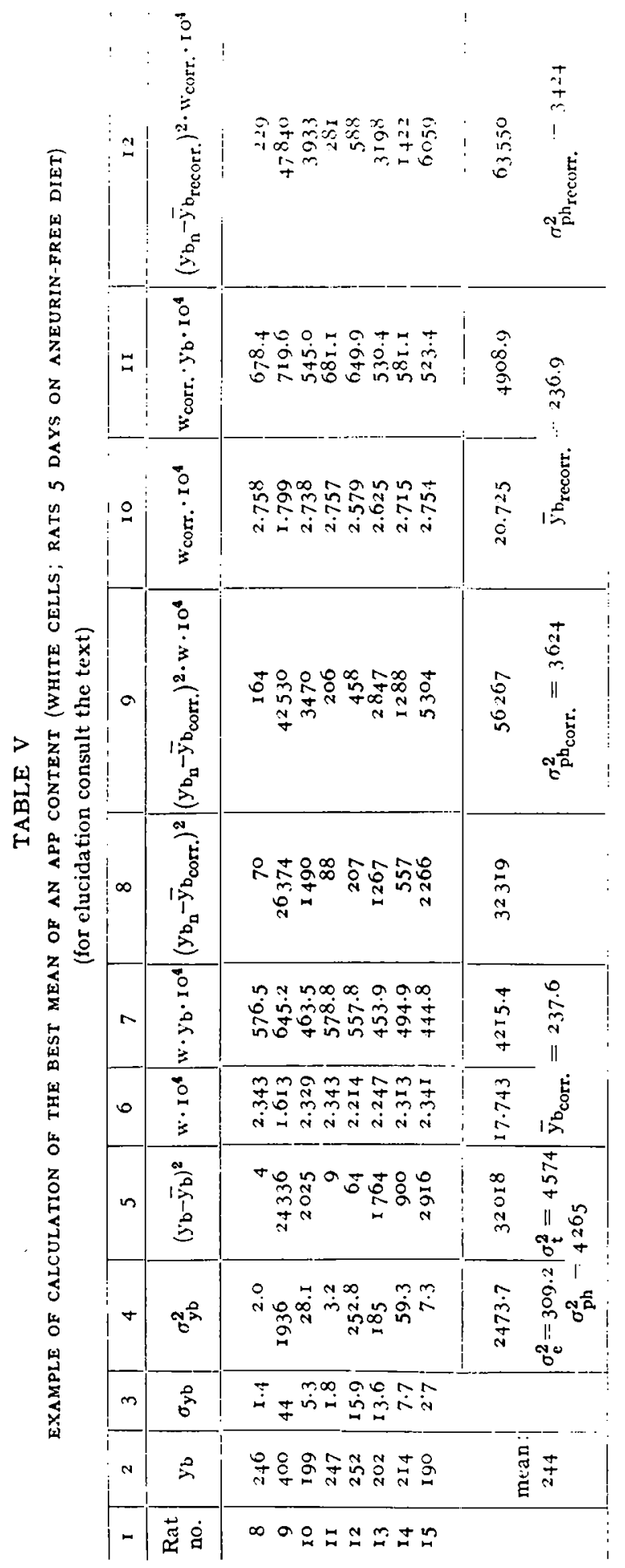

References $p .64$. 
$\sigma_{\mathrm{t}}^{2}$ is calculated in column 5: $\sigma_{\mathrm{t}}^{2}=\frac{\sum\left(\mathrm{y}_{\mathrm{b}_{\mathrm{n}}}-\overline{\mathrm{y}}_{\mathrm{b}}\right)^{2}}{\mathrm{n}-\mathrm{I}}$.

The weight of an observation $w=\frac{I}{\sigma_{\mathrm{ph}}^{2}+\sigma_{\mathrm{e}_{\mathrm{p}}}^{2}}($ column 6).

A corrected mean is now calculated: $\bar{y}_{b_{\text {corr. }}}=\frac{\sum w_{n} y_{n}}{\sum w_{n}}$ (columns 6 and 7 ).

The tentative physiological scattering can now be replaced by a calculated value, considering that also the deviation of an observation from the mean does not always carry the same weight:

$$
\sigma_{\mathrm{ph}_{\text {corr. }}}^{2}=\frac{\sum \mathrm{w}_{\mathrm{n}}\left(\mathrm{y}_{\mathrm{b}_{\mathrm{n}}}-\overline{\mathrm{y}}_{\mathrm{b}}\right)^{2}}{\sum \mathrm{w}_{\mathrm{n}}} \cdot \frac{\mathrm{n}}{\mathrm{n}-\mathrm{I}} \text { (column 9). }
$$

Should the corrected mean deviate markedly from the tentative arithmetical mean computed in column 2, then it is desirable to regard this corrected mean as a new tentative mean and to repeat the correction in the same manner, now using the corrected physiological scattering.

This calculation may seem excessively extensive for such a limited material. Nevertheless it is not so much out of place here as with an extensive material, for in the latter case a sufficiently large number of observations falls by random within the limits of each range of accuracy.

The corrected means thus obtained are summarized in Table VI.

TABLE VI

CORRECTED MEANS OF APP CONTENTS OF BLOOD CELLS AND TISSURS OF THE RAT

$(Q=$ ratio of APP contents of a white and a red cell)

\begin{tabular}{|c|c|c|c|c|c|c|c|}
\hline \multirow[b]{2}{*}{ Subjects } & \multirow{2}{*}{$\begin{array}{l}\gamma \text { APP per } \\
\text { IO11 red cells } \\
\pm \text { S.D. }\end{array}$} & \multirow{2}{*}{$\begin{array}{c}\gamma \text { APP per } \\
\text { roll white cells } \\
\pm \text { S.D. }\end{array}$} & \multirow[b]{2}{*}{$Q$} & \multicolumn{4}{|c|}{$\gamma$ APP per gram } \\
\hline & & & & liver & kidney & $\begin{array}{l}\text { leg- } \\
\text { muscle }\end{array}$ & brain \\
\hline Well-nourished rats & $2.1 \pm 0.41$ & $34^{\circ} \pm \mathrm{IOI}$ & 160 & 12.5 & 7.0 & 2.4 & 3.8 \\
\hline $\begin{array}{l}\text { Rats after } 5 \text { days on } \\
\text { aneurin-deficient ration }\end{array}$ & $1.0 \pm 0.19$ & $24^{\circ} \pm 5^{8}$ & 240 & $4 \cdot 1$ & 2.7 & 1.25 & 3.1 \\
\hline $\begin{array}{l}\text { Decrease after } 5 \text { days } \\
\text { on aneurin-deficient ra- } \\
\text { tion }\end{array}$ & $\begin{array}{c}52 \% \\
t=6.8 \\
n=\mathrm{I}_{3} \\
\mathrm{P} \ll \mathrm{o} .01 \\
\text { very significant }\end{array}$ & $\begin{array}{c}30 \% \\
t=2.4 \\
n=13 \\
0.02<\mathrm{P}<0.05 \\
\text { significant }\end{array}$ & & $67 \%$ & $62 \%$ & $48 \%$ & $18 \%$ \\
\hline
\end{tabular}

These results show that in the case of the well-fed rat an average leucocyte contains I6o times as much APP as an average erythrocyte. After 5 days on an aneurin-free diet the content of the red cells has decreased more than that of the white cells. In agreement herewith the ratio of the contents of a white and a red cell has risen to 240 .

For the average normal rat with an average number of erythrocytes of $7.8 \cdot 10^{6}$ and of leucocytes of $0.012 \cdot 10^{6}$ per $\mu \mathrm{l}$ of blood, one will therefore find that per $100 \mathrm{ml}$ of blood, containing $20.5 \gamma \mathrm{APP}$, on the average $16.4 \gamma$ or $80 \%$ is present in the erythrocytes and $4.1 \gamma$ or $20 \%$ in the leucocytes.

References p. 64 . 

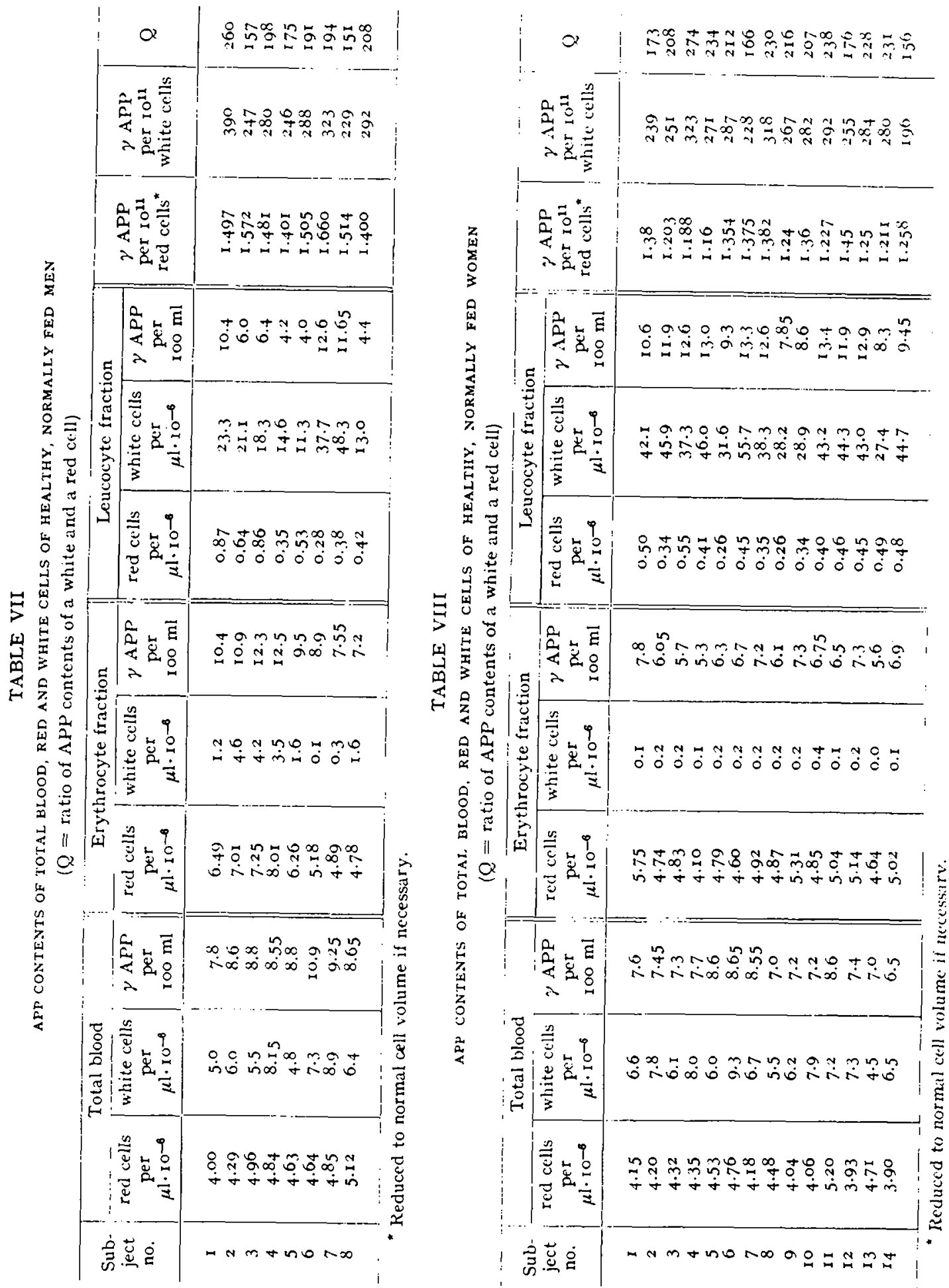

References $p .64$. 
APP content of red and white blood cells of healthy human subjects on normal and aneurindeficient diets

Table VII gives the results of the determinations of APP in blood of 8 men and Table VIII those for $\mathrm{I}_{4}$ women, while Table IX shows the corrected means of these determinations.

TABLE IX

CORRECTED MEANS OF APP CONTENTS OF BLOOD CELLS AND OF TOTAL BLOOD OF HEALTHY, NORMALLY FED MEN AND WOMEN

\begin{tabular}{|c|c|c|c|c|}
\hline & $\begin{array}{l}\gamma \text { APP per Io } 11 \\
\text { red cells } \pm \text { S.D. }\end{array}$ & $\begin{array}{c}\gamma \text { APP per Io } 11 \\
\text { white cells } \pm \text { S.D. }\end{array}$ & $Q$ & $\begin{array}{l}\gamma \text { APP per } 100 \mathrm{ml} \\
\text { total blood } \pm \text { S.D. }\end{array}$ \\
\hline Men & $\mathrm{r} .49 \pm 0.083$ & $290 \pm 53$ & 195 & $8.9 \pm 0.9$ \\
\hline Women & $1.28 \pm 0.088$ & $27^{\circ} \pm 34$ & 210 & $7.6 \pm 0.7$ \\
\hline Difference & $\begin{array}{c}\text { very significant } \\
\mathbf{t}=5.5 \\
\mathrm{n}=20 \\
\mathrm{P}<0.00 \mathrm{I}\end{array}$ & not significant & $\begin{array}{l}\text { not } \\
\text { significant }\end{array}$ & $\begin{array}{c}\text { very significant } \\
\qquad \begin{array}{c}\mathrm{t}=3.8 \\
\mathrm{n}=20 \\
\mathrm{P}<0.00 \mathrm{I}\end{array}\end{array}$ \\
\hline
\end{tabular}

In the course of these determinations and of experiments with blood of patients as described below we observed cases with unusually high APP contents of the red cells. These cells appeared to have abnormally large volumes. After these observations had been made we determined the mean corpuscular volume $\left(=\frac{\text { haematocrit volume }(\% \text { of total blood })}{\text { number of erythrocytes } \times 10^{-7} \text { per } \mu \text { l }}\right)$ ef each sample of blood investigated. The normal average of the mean corpuscular volume is 87 . As the amount of APP present in a red cell may be expected to be proportional to the volume of the cell, all APP contents pertaining to red cells in Tables VI and VII are reduced to the average cell volume, viz., the cell volume corresponding with the mean corpuscular volume 87 .

The determination of the mean corpuscular volume had been omitted in the first experiments carried out with human blood. It was estimated some months later, after we had become aware of its importance. The mean corpuscular volume of these bloods deviated only very little from 87 , while the mean corpuscular volume of the blood of an individual which had been found to be abnormally high some months earlier had retained this high value. Hence we did not hesitate also to include in Table VII the results obtained without simultaneous determination of the mean corpuscular volume.

The figures in Tables VII to IX demonstrate that the observed differences in APP content between the erythrocytes and between the total blood of men and women are very significant, while the difference between the leucocytes of both sexes is not significant. The contents of total blood could be expected to differ for both sexes, as their red cell counts are not the same. But the difference is larger than could be expected on these grounds, owing to the different APP content of the erythrocytes of men and women.

The standard deviation of the APP contents of the white cells is much larger than that of the red cells. This may be due to larger experimental errors in counts and APP determinations in the case of the white cells. When these larger experimental errors are accounted for in calculating the probability that the divergence of the standard deviations for red and white cells be due to random causes, the latter difference appears also to have a physiological cause. In other terms: there exists a significant difference between the biological variations of the APP content of white and red cells. $(F=2.34$; $\left.\mathrm{n}_{1}=\mathrm{I} 9 ; \mathrm{n}_{\mathbf{8}}=\mathrm{I} 9 ; \mathrm{P}<0.05^{\star \star}\right)$.

- For method of calculation, see example in Table $V$.

* A. Linder, Statistische Methoden, Birkhäuser, Basel, I945, p. 57.

References p. 64 . 
The larger biological variation of the APP content of the white cells may be caused by variations in the ratios of the numbers of the various forms of white cells and by differences in the age of these cells. In one individual the white cell count is subject to much larger fluctuations than the red cell count. Therefore much greater differences in the rate of cell production and so in the mean age of the white cells may be expected to occur. The possible influence of the age of the cells on their APP content is rendered probable by the observation, in blood of patients suffering from pernicious anaemia and erythroblastosis foetalis (as described below), that in an carlier stage of development red cells contain more APP than in a later stage. It seems possible that this also applies to white cells, including variations in the age of mature cells.

TABL.F X

APP CONTENTS OF TOTAL BLOOD AND REI ANI WHITE BLOOD CELLS OF HEALTHY INDIVIDUALS ON AN ANELRIN-DEFICIENT IJIET

\begin{tabular}{|c|c|c|c|c|c|}
\hline $\begin{array}{l}\text { Sub- } \\
\text { ject }\end{array}$ & $\begin{array}{l}\text { Days } \\
\text { on diet }\end{array}$ & $\begin{array}{c}\gamma \text { APP per I } 00 \mathrm{ml} \\
\text { total blood }\end{array}$ & $\begin{array}{l}y \text { APP per Io } \\
\text { red colls : S.I). }\end{array}$ & $\begin{array}{c}\gamma \text { APP per Io } 11 \\
\text { white cells } \perp \text { S.D. }\end{array}$ & Remarks \\
\hline$A, \boldsymbol{\delta}$ & $\begin{array}{r}0 \\
2 \\
4 \\
6 \\
8 \\
\text { 10 }\end{array}$ & $\begin{array}{l}8.9 \\
8.6 \\
6.0 \\
5.3 \\
6.4 \\
5.6\end{array}$ & $\begin{array}{l}1.53 \pm 0.060 \\
1.50 \pm 0.046 \\
1.21 \pm 0.106 \\
1.06 \pm 0.173 \\
1.16 \pm 0.055 \\
1.13 \pm 0.022\end{array}$ & $\begin{array}{l}280 \pm 15 \\
292 \pm \therefore \\
21.4 \pm 36 \\
156 \pm 53 \\
180 \cdot t=21 \\
139: 1-5\end{array}$ & \\
\hline$B, \delta$ & $\begin{array}{r}0 \\
5 \\
\text { IO }\end{array}$ & $\begin{array}{l}9.0 \\
7.6 \\
6.9\end{array}$ & $\begin{array}{l}1.54 \pm 0.075 \\
1.27 \pm 0.060 \\
1.11 \pm 0.007\end{array}$ & $\begin{array}{l}3 \mathbf{I}=3 \mathbf{I} \\
297 \neq 2 \mathrm{I} \\
243 \pm 2\end{array}$ & \\
\hline C, $q$ & $\begin{array}{r}0 \\
6 \\
10\end{array}$ & $\begin{array}{l}7 \cdot 6^{5} \\
6.6 \\
5.2\end{array}$ & $\begin{array}{l}1.3^{8} \text { t: } 0.065 \\
1.22 \text { t: } 0.025 \\
1.03 \div 0.022\end{array}$ & $\begin{array}{l}239 \pm 17 \\
277-1=7 \\
191+6\end{array}$ & $\begin{array}{l}\text { menstruation on the } \\
4^{\text {th }} \text { day of the diet }\end{array}$ \\
\hline D. & $\begin{array}{r}0 \\
4 \\
10\end{array}$ & $\begin{array}{l}8.8 \\
7 \cdot 5 \\
7 \cdot 1\end{array}$ & $\begin{array}{l}1.505 \pm 0.086 \\
1.23 \pm 0.060 \\
1.21 \pm 0.043\end{array}$ & $\begin{array}{l}288 \div 38 \\
218 \div 24 \\
217 \pm 20\end{array}$ & $\begin{array}{l}\text { on the } 6 \text { th day } 200 \mathrm{~g} \text { of } \\
\text { syrup was consumed } \\
\text { containing } 2 \mathrm{mg} \text { aneurin }\end{array}$ \\
\hline $\mathrm{E}, \vec{\jmath}$ & $\begin{array}{r}0 \\
5 \\
10\end{array}$ & $\begin{array}{l}7.7 \\
6.9 \\
6.5\end{array}$ & $\begin{array}{l}1.37 \pm 0.052 \\
1.24 \pm 0.042 \\
1.25 \pm 0.062\end{array}$ & $\begin{array}{l}235 \div 13 \\
203=12 \\
200 \pm 20\end{array}$ & \\
\hline$F, \sigma$ & $\begin{array}{r}0 \\
5 \\
10\end{array}$ & $\begin{array}{r}10.9 \\
8.1 \\
7.8\end{array}$ & $\begin{array}{l}1.66^{*} \pm 0.062 \\
1.24^{*} \pm 0.010 \\
1.28^{*} \pm 0.04^{\circ}\end{array}$ & $\begin{array}{l}323 \pm 12 \\
258 \pm 3 \\
202 \pm 9\end{array}$ & \\
\hline$G, \widehat{\delta}$ & $\begin{array}{r}4 \\
10\end{array}$ & $\begin{array}{l}8.2 \\
6.7\end{array}$ & $\begin{array}{l}\text { I.32 } \pm 0.080 \\
\text { I.II } \pm 0.00 \mathrm{I}\end{array}$ & $\begin{array}{l}234 \pm \mathrm{I} 6 \\
\mathrm{I} 84 \pm \mathrm{I}\end{array}$ & \\
\hline
\end{tabular}

* Reduced to normal cell volume.

Table $\mathrm{X}$ contains the results of determinations carried out with 7 healthy men and women, subjected to an aneurin-deficient diet consisting of: boiled or steamed polished References p. 64 . 
rici, which had been carefully washed with tap water, butter fat (repeatedly melted with water), sugar, the white of 8 eggs daily, tea without milk and some condiments. Rice, butter and sugar were consumed ad libitum. This diet was followed for Io days.

It was impossible to give a statistical evaluation of the figures in Table $X$ as the per $10^{\text {nerythrocytes }}$ number of individuals of equal sex is too small and the determinations were carried out at various times after the beginning of the diet. That only few individuals were subjected to this experiment was due to the fact that only people convinced of the importance of strict adherence to the diet could be trusted not to take any other food. Causes beyond our control prevented us from examining the subjects on the same day of the dietary period.

Notwithstanding these imperfections we feel justified in concluding that the APP content of red and white cells decreases rather rapidly on an aneurin-free diet. Presuming that the decrease proceeds at a constant rate we can calculate from the values found at the beginning and the end of the ten-day period (Fig. 6) that after 4.3 and 5.7 days respectively the APP content of red and white cells decreased to a value significantly lower than normal.

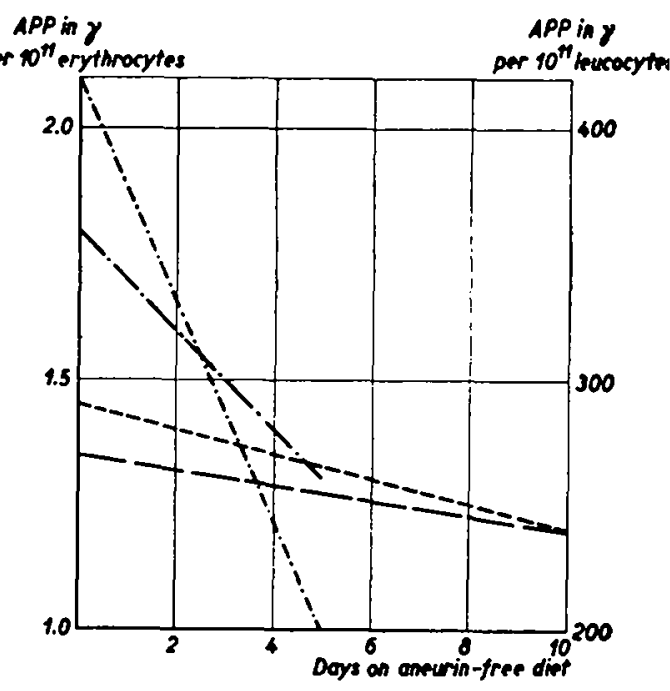

Fig. 6. Average decrease of the APP content of the blood cells of human subjects and rats on an aneurin-free diet

- - - - erythrocytes of human blood

- - leucocytes of human blood

-...- leucocytes of rat blood

-....-..- erythrocytes of rat blood

$A P P$ content of blood cells of patients suffering from various diseases characterized by abnormal corpuscular composition of the blood, and of patients suffering from aneurin deficiency

We have investigated eight patients only, but this small number was sufficient to prove that deviations from the normal corpuscular composition of the blood cause deviations from the normal APP content of the blood, the latter bearing no relation whatsoever to the aneurin provision of the body.

TABLE XI

PATIENT I (PERNICIOUS ANAEMIA)

\begin{tabular}{|c|c|c|c|c|c|c|c|c|}
\hline & \multirow{2}{*}{$\begin{array}{l}\text { red cells per } \\
\mu 1 \text { total } \\
\text { blood } \\
\times \text { ro-0 }\end{array}$} & \multirow{2}{*}{$\begin{array}{l}\text { white cells } \\
\text { per } \mu \text { ] } \\
\text { total blood } \\
\times 10^{-6}\end{array}$} & \multirow[b]{2}{*}{$\begin{array}{l}\text { reticu- } \\
\text { locytes }\end{array}$} & \multirow{2}{*}{$\begin{array}{l}\text { mean } \\
\text { corpuscular } \\
\text { volume }\end{array}$} & \multicolumn{4}{|c|}{$\gamma$ APP per } \\
\hline & & & & & $\begin{array}{l}\text { Ioo ml } \\
\text { total } \\
\text { blood }\end{array}$ & $\begin{array}{l}\text { so } 11 \text { red } \\
\text { cells }\end{array}$ & $\begin{array}{c}10^{11} \text { white } \\
\text { cells }\end{array}$ & $\begin{array}{l}10^{11} \text { red cells } \\
\text { of normal } \\
\text { volume }\end{array}$ \\
\hline 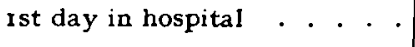 & 2.45 & 0.0037 & $7 \%$ & 132 & $7 \cdot 1$ & 2.68 & 200 & I. 77 \\
\hline $\begin{array}{l}\text { After } 4 \text { weeks in hospital, just } \\
\text { before "Pernaemon" treatment }\end{array}$ & 2.01 & 0.0043 & $12 \%$ & I I 2 & 6.8 & $2.7^{\circ}$ & 300 & 2.10 \\
\hline After 5 days' "Pernaemon". . & 2.32 & 0.0041 & $40 \%$ & 100 & $7 \cdot 3$ & 2.86 & 220 & 2.49 \\
\hline
\end{tabular}


Patient I was a man suffering from pernicious anaemia, characterized by anisocytosis, poikilocytosis and polychromasia. The red cells were much larger than normal. During our investigation of this patient treatment with liver ("Pernaemon', Organon) was begun. The results are summarized in Table XI. Most workers in this field would consider the APP content of the total blood before treatment to be normal (about $7 \gamma$ per roo $\mathrm{ml}$ ). Also in our opinion it lies in the normal range. Yet the number of red cells is much below the normal value. But this is compensated by the abnormally high amount of APP per red cell.

Pannekoek-Westenburg and Van Veen ${ }^{23}$, Oosterhuis ${ }^{15}$ and Rowlands and Wilkinson ${ }^{24}$ have also determined aneurin or APP in blood of normal persons and patients suffering from diverse anaemias. They have tried to establish a positive correlation between aneurin (APP) content and red cell count. In Pansekoek-Westenburg and VAs Veen's opinion part of the low ancurin values observed might be ascribed to the low red cell count in these cases of anaemia. OosterHuis arrived at a similar conclusion. ROWLANDS AND WILKINSON found a difference between pernicious anaemia and anaemia caused by iron deficiency. These authors observed normal aneurin values in their pernicious anaemia patients and concluded that in these cases no correlation existed between aneurin content and red cell count. The low aneurin content in iron deficiency would be caused by a simultaneous lack of aneurin in the food. Hence in gencral no correlation seemed to exist between aneurin (APP) content of total blood and red cell count.

In our opinion this correlation does indeed exist. That the investigators mentioned above failed to establish this correlation has various causes:

I. they omitted to count the white cells;

2. they compared blood of healthy people to that of patients without accounting for the fact that the red cells of the latter are, as regards age and volume, not strictly comparable to the cells of normal blood.

RowlandS AND WiLkinson's results can be explained as follows:

In pernicious anaemia normal ancurin (APP) contents of total blood are found owing to two factors with opposite effect:

I. a number of red cells below normal;

2. a higher average amount of APP per red cell.

In the anaemia due to iron deficiency the APP content is lowered, owing to two factors with the same effect:

I. a lowered number of red cells;

2. a lowered amount of APP per red cell, due to the increased average age of the red cells or the abnormally small volume of them.

An abnormally low APP content of the blood does not nccessarily indicate ancurin deficiency, but may be caused by an abnormal corpuscular composition of the blood.

Considering the figures in Table XI one observes that the APP content of total blood remains constant notwithstanding 5 days of "Pernaemon" treatment. The mean corpuscular volume had declined, but the average amount of APP per red cell did not show a corresponding decrease. Reduced to normal volume the APP content of the red cells is even increased. Liver therapy causes the apparition in the blood of a large number of young erythrocytes, as is shown in Table XI by the rise of the percentage of reticulocytes. Obviously these cells have a higher APP content than fully matured cells.

The investigation of patients II, III and IV furnished more evidence for the assumption that the APP content of the red cells decreases with increasing age.

Patient II was a woman suffering from severe haemorrhage caused by carcinoma of the liver. Thete was a very active regeneration of red cells; even normoblasts $15 \%$ leucocytes) were observed in peripheral blood. The results of our determinations are summarized in Table XII. The number of red cells is very low. Yet the APP content of the total blood is higher than that of the healthy women we examined. This is explained by the fact that the average amount of APP per red cell is considerably higher than normal. Also in this case the increased APP content of the red cells appears to correspond with a lower average age of these cells.

References p. 67 . 
TABLE XII

PATIENT II (SEvere haEmorRhage caused by CARCiNoma of the liver)

\begin{tabular}{c|c|c|c|c|c|c}
\hline $\begin{array}{c}\text { Red cells } \\
\text { per } \mu 1 \\
\text { total blood } \\
\times 10^{-6}\end{array}$ & $\begin{array}{c}\text { White cells } \\
\text { per } \mu \mathrm{l} \\
\text { total blood } \\
\times 10^{-6}\end{array}$ & $\begin{array}{c}\text { Mean } \\
\text { corpuscular } \\
\text { volume }\end{array}$ & $\begin{array}{c}\text { 100 ml } \\
\text { total blood }\end{array}$ & $\begin{array}{c}10^{11} \text { red } \\
\text { cells }\end{array}$ & $\begin{array}{c}\text { I0 } \\
\text { cells }\end{array}$ & $\begin{array}{c}\text { white } \\
\text { of normal } \\
\text { volume }\end{array}$ \\
\hline & 0.0204 & 97 & 9.9 & 2.50 & 340 & 2.34 \\
\hline
\end{tabular}

Patients III and IV were two new-born children suffering from erythroblastosis foetalis. The blood contained many reticulocytes and nucleated erythrocytes. We were able to determine the APP content of the latter by further fractional centrifuging of the red cell fraction of the blood. This content appeared to be extremely high ,viz., Ioo to $160 \gamma$ per Io 11 cells, while the non-nucleated red cells contained 5 to $6 \gamma$ and the white cells 100 to $200 \gamma$ per ${ }^{10}{ }^{11}$ cells. Even the content of the non-nucleated red cells is very high when compared to red cells of healthy adults. These observations confirm our provisory conclusion, mentioned above, that red cells in earlier stages of development or young cells contain more APP than older cells.

TABLE XIII

PATIENT $V$ (LYMPHATIC LEUCAEMIA OR LYMPHOSARCOMA)

\begin{tabular}{c|c|c|c|c|c|c}
\hline $\begin{array}{c}\text { Red cells } \\
\text { per } \mu \mathrm{l} \\
\text { total blood } \\
\times 10^{-6}\end{array}$ & $\begin{array}{c}\text { White cells } \\
\text { per } \mu \mathrm{l} \\
\text { total blood } \\
\times 10^{-0}\end{array}$ & $\begin{array}{c}\text { Mean } \\
\text { corpuscular } \\
\text { volume }\end{array}$ & $\begin{array}{c}\text { Ioo ml } \\
\text { total blood }\end{array}$ & $\begin{array}{c}\text { Iol red } \\
\text { cells }\end{array}$ & $\begin{array}{c}\text { Io } \\
\text { cells white }\end{array}$ & $\begin{array}{c}\text { Io } \\
\text { of normal } \\
\text { volume }\end{array}$ \\
\hline 2.23 & 0.0089 & 100 & 5.3 & 1.60 & 200 & 1.40 \\
\hline
\end{tabular}

Table XIII refers to the examination of a well-nourished man (patient V) suffering from either lymphatic leucaemia or lymphosarcoma. The figures show that the number of red cells is lowered, while the number of white cells and the APP contents of both kinds of cells are normal. The APP content of total blood, however, is lower than the lowest value observed in the healthy subjects we examined. This is merely due to the lowered number of red cells and must not be ascribed to a shortage in aneurin provision. This case proves decisively that one is not justified in concluding to aneurin deficiency from determination of APP in total blood alone.

TABLE XIV

PATIENT Vi (MYeloid leUCAEMia)

\begin{tabular}{c|c|c|c|c}
\hline $\begin{array}{c}\text { Red cells per } \mu \mathrm{l} \\
\text { total blood } \times 10^{-6}\end{array}$ & $\begin{array}{c}\text { White cells per } \mu \mathrm{l} \\
\text { total blood } \times 10^{-0}\end{array}$ & \multicolumn{3}{|c}{$\gamma$ APP per } \\
\hline $1.7^{8}$ & 0.686 & 218 & $100 \mathrm{ml}$ total blood & 10 \\
\hline
\end{tabular}

Examination of patient VI, a child suffering from myeloid leucaemia, showed that normal aneurin provision can also concur with an extremely high APP content of total blood (see Table XIV). The APP content of both white and red cells was quite normal. The high APP content of total blood is solely caused by the extremely high number of white cells. This child might have suffered from severe aneurin deficiency while the APP 
content of the total blood would still have been much higher than normal. This supposed aneurin deficiency would not have been detected by determination of APP in total blood alone.

The next patients were suspected to suffer from aneurin deficiency. Patient VII was a woman with pylorus stenosis. She was nourished by plasma infusions. The figures in Table XV demonstrate that the number of red cells is only slightly lowered, but that the APP content of total blood as well as that of red and white cells has decreased considerably. Hence these determinations confirm the occurrence of aneurin deficiency as was expected from the anamnesis.

TABLE XV

PATIENT V'II (PYLORLS STENOSIS)

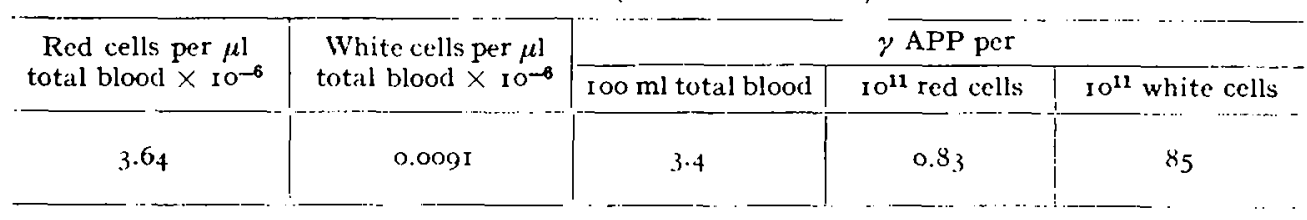

Patient VIII was a man suffering from tropical sprue, with the usual disturbance of intestinal absorption. Determinations were carried out before and after treatment with $2 \mathrm{mg}$ aneurin daily during one month. Table XVI shows the results. The APP content of total blood, red and white cells was very low previous to the administration of aneurin and normal after treatment. The patient was obviously suffering from aneurin deficiency.

TABLE XVI

PATIENT VIII (TROPICAL SPRUE)

\begin{tabular}{|c|c|c|c|c|c|c|c|}
\hline & \multirow{2}{*}{$\begin{array}{l}\text { Red cells } \\
\text { per } \mu \mathrm{l} \\
\text { total blood } \\
\times 10^{-6}\end{array}$} & \multirow{2}{*}{$\begin{array}{l}\text { White cells } \\
\text { per } \mu \mathrm{b} \\
\text { total blood } \\
\times \text { ro }^{-8}\end{array}$} & \multirow{2}{*}{$\begin{array}{l}\text { Wean } \\
\text { corpus- } \\
\text { cular } \\
\text { volume }\end{array}$} & \multicolumn{4}{|c|}{$\gamma$ APP per } \\
\hline & & & & $\begin{array}{c}\text { Ion ml } \\
\text { total } \\
\text { blood } \\
\end{array}$ & $\begin{array}{l}\text { Io }{ }^{11} \text { red } \\
\text { cells }\end{array}$ & $\begin{array}{l}\text { Iol1 white } \\
\text { cells }\end{array}$ & $\begin{array}{l}\text { of red cells } \\
\text { of normal } \\
\text { volume }\end{array}$ \\
\hline Before treatment & 4.23 & 0.0080 & 102 & 3.2 & 0.62 & 80 & 0.53 \\
\hline $\begin{array}{l}\text { After treatment } \\
\text { with aneurin }\end{array}$ & 3.10 & 0.0096 & 1.06 & 8.0 & 1.65 & 275 & $1 \cdot 36$ \\
\hline
\end{tabular}

The general conclusion from our examination of these patients is that it is possible to detect aneurin deficiency by determination of APP in blood, but that this must be combined with accurate study of the corpuscular composition of the blood. Separate determination in both red and white cells is to be preferred to determination in total blood, but even then the haematological examination should not be omitted.

\section{SUMMARY}

r. Methods are described for accurate counting of red and white blood cells and for the determination of the aneurinpyrophosphate (APP) content of these cells.

2. These methods were applied to: a) rat blood (adequately nourished rats and rats on an aneurin-deficient diet); b) human blood (healthy subjects on their usual diet or on an aneurindeficient diet, and patients). Moreover APP was determined in liver, kidney, brain and leg-muscle of the rats.

3. The mean values of the APP contents of the blood cells and the tissues of the adequately nourished rats were: red cells : $2.1 \%$ per $10^{11}$ cells; white cells : $34^{\circ} \gamma$ per $10^{11}$ cells; liver: $12.5 \gamma$ per g;

References p. 64 . 
kidney : $7.0 \gamma$ per $g$; brain : $3.8 \gamma$ per $g$; leg-muscle : $2.4 \gamma$ per $g$. For rats after 5 days on an aneurin-free diet these values were: red cells: $1.0 \gamma$ per 10 ${ }^{11}$ cells; white cells: $24^{0} \gamma$ per Io $^{11}$ cells; liver: $4.1 \gamma$ per g; kidney : $2.7 \gamma$ per g; brain: $3.1 \%$ per $g$; leg-muscle : $1.25 \gamma$ per $g$. In the well-fed rat an average leucocyte contains 160 times as much APP as an average erythrocyte. After 5 days without aneurin the ratio of the contents of a white and a red cell has risen to 240 . So on an aneurin-frce diet the content of the red cells decreases more rapidly than the content of the white cells.

4. The red blood cells of the man have a significantly higher APP content than the red cells of the woman. No significant difference was found between the respective contents of the white cells. The average values were: $\operatorname{man}: 1.49 \gamma$ per $10^{11}$ red cells, $290 \gamma$ per $10^{11}$ white cells; woman: $1.28 \gamma$ per $10^{11}$ red cells, $270 \gamma$ per $10^{11}$ white cells. The ratio of the contents of a white and a red cell is about 200 .

5. In men on an aneurin-free diet the APP content of red cells decreases after 5 days to a value significantly lower than normal. White cells appear to lose their APP at approximately the same rate.

6. Red cells in earlier stages of development, as occurring in the blood of some anaemia patients, contain higher amounts of APP than normal red cells. This is also the case for red cells with an abnormally large volume. As a consequence of the abnormal APP contents of the blood of anaemia patients abnormal APP contents of total blood can occur, bearing no relation to the aneurin provision of the body. Therefore a haematological examination should be combined with each APP determination in blood aimed at the detection of a possible ancurin deficiency. The determination of APP in red and white cells is to be preferred to the determination in total jblood. Examples are given in which the occurrence of aneurin deficiency could be proved to exist by working along these lines.

\section{RESUME}

I. Description de méthodes pour la numération précise des globules rouges et des globules blancs et pour le dosage de la teneur en pyrophosphate d'aneurine (APP) de ces cellules.

2. Ces méthodes ont été appliquées a : a) du sang de rat (rats soumis à un régime complet et rats soumis à un régime carencé en aneurine); b) du sang humain (individus normaux soumis a leur régime habituel ou à un régime carencé en aneurine, et individus en état pathologique). En outre, l'APP a été dosée dans le foie, le rein, le cerveau et la musculature des pattes des rats.

3. Les valeurs moyennes des teneurs en APP des éléments du sang et des tissus des rats soumis à un régime complet sont les suivantes: globules rouges: $2.1 \gamma$ par Io 11 cellules; globules blancs: $340 \gamma$ par I $0^{11}$ cellules; foie: $12.5 \gamma$ par $\mathrm{g}$; rein: $7.0 \gamma$ par g; cerveau : $3.8 \gamma$ par $\mathrm{g}$; musculature de la patte: $2.4 \gamma$ par $\mathrm{g}$. Chez les rats soumis pendant 5 jours à un régime carencé en aneurine, on a trouvé: globules rouges: 1.o $\gamma$ par Iol1 cellules; globules blancs: $240 \gamma$ par Io ${ }^{11}$ cellules; foie: $4.1 \gamma$ par g; rein: $2.7 \gamma$ par $g$; cerveau: $3.1 \gamma$ par $g$; musculature de la patte: $1.25 \gamma$ par $g$. Chez le rat soumis a un régime complet, un leucocyte moyen contient 160 fois plus de APP qu'un érythrocyte moyen. Apres 5 jours de carence en aneurine, le rapport des teneurs d'un globule blanc et d'un globule rouge monte à $24^{\circ}$. Ainsi, chez les animaux soumis à un régime carencé en aneurine, la teneur des globules rouges décroit plus rapidement que celle des globules blancs.

4. Les globules rouges du sang de l'homme ont une teneur en APP nettement supérieure a celle des globules rouges de la femme. Aucune différence nette n'a été trouvée en ce qui concerne les teneurs respectives en APP des globules blancs. Les valeurs moyennes sont: homme: $1.49 \gamma$ par $10^{11}$ globules rouges, $290 \gamma$ par $10^{11}$ globules blancs; femme: $1.28 \gamma$ par $10^{11}$ globules rouges, $270 \gamma$ par $10^{11}$ globules blancs. Le rapport des teneurs d'un globule blanc et d'un globule rouge est environ 200 .

5. Chez des hommes soumis à un régime carencé en aneurine, la teneur en APP des globules rouges décroit après 5 jours d'une façon nette. Les globules blancs perdent leur APP approximativement à la même vitesse.

6. Les globules rouges dans leur premier stade de développement, tels qu'on les rencontre dans e sang de quelques malades souffrant d'anémie, contiennent des quantités de APP supérieures à la teneur normale des globules rouges. Le même phénomene se retrouve chez les globules rouges anormalement gros. Il en résulte que chez les malades souffrant d'anémie, on peut rencontrer des teneurs anormales du sang total en APP, qui n'ont rien à voir avec la réserve en aneurine de l'organisme. Aussi, conviendrait-il de combiner un examen hématologique avec chaque dosage de l'APP dans le sang fait en vue de déceler une carence éventuelle en aneurine. On doit préférer un dosage de l'APP dans les globules rouges et les globules blancs a un dosage dans le sang total. Des exemples sont donnés montrant qu'il est possible de caractériser des carences en aneurine par cette methode.

\section{ZUSAMMENFASSUNG}

I. Methoden zur genauen Zählung der roten und weissen Blutkörperchen und zur Bestimmung des Aneurinpyrophosphat (APP)-Gehaltes dieser Zellen werden beschrieben.

References $p .64$. 
2. Die Methoden wurden auf: a) Rattenblut (Ratten auf vollständigem Futter und Ratten aut aneurinarm(r Diät); b) Menschenblut (gesunde Personen auf ihrer gewöhnlichen Diät oder auf aneurinarmer Diät, und Patienten) angewandt. Ausserdem wurde APP in der Leber, Niete, dem Gehirn und dem Benmuskel der Katten bestimmt.

3. Die Jurchschnittswerte des APP-(iehaltes der Blutkërperchen und Gewebe der Ratten auf vollständiger Nahrung betrugen: rote Blutkörperchen : 2.1 pro ioll Zellen; weisse Blutkörperchen: $34^{\circ} \gamma$ 10 11 Zellen: Leber: $12.5 \gamma$ prog; Niert: $7.0 \%$ pro g; (iehirn: $3.8 \gamma$ pro g; Beinmuskel: $2.4 \gamma$ pro g. Bei Ratten, die fünf Tage aneurinfrei ernährt walen, betrugen diese Werte: rote Blutkörper-

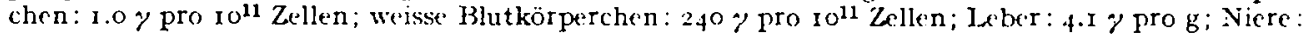
$2.7 \gamma$ prog; Gehirn: $3.1 \%$ pro g; Beinmuskel: $1.25 \gamma$ pro g. Bei gutgefütterten Ratten enthält ein Leukozyt im Durchschnitt ungefähr i 60 mal soviel APP wie ein Frythrozyt. Nach fünf lagen ohne: Aneurin steigt las Verhältnis des Gehaltes eines weissen und roten J3lutkörperchens auf 240 . 13e-1 aneurinfreier Diät nimmt also der (;ehalt der roten Blutkörperchen schneller ab als der der weissen.

4. Die roten I3lutkörperclien des Mannes haben einen bedeutend höheren APP-Gehalt als die der Frau, während beei den weissen Blutkörperchen kein signifikanter Unterschied gefunden wurde. Dic Durchschnittswerte betrugen: Mann: rote Blutkörperchen: $1.49 \gamma$ pro roll Zellen, weisse Blutkörperchen: $290 \gamma$ pro $10^{11}$ Zellen; Frau: rote I3lutkörperchen: 1.28 y pro $10^{11}$ Zellen, weisse Blutkörperchen : $270 \gamma$ pro $10^{11}$ Zellen. Das Verhältnis des Gehalts eines weissen und roten Blutkörjerchens beträgt ungefähr 200 .

5. Beim Menschen sinkt nach fünf Tagen ohne Ancurin der APP-Gehalt der roten Blutkörperchen auf einen Betrag, der stark unter dem normalen liegt. Weisse Blutkörperchen scheinen ihr APP ungefähr in clemselben Mass zu verlieren.

6. Rote Hlutkörperchen in frühen Entwicklungsstadien, wie sie im Blut mancher Anämiepatienten vorkommen, enthalten höhere $\Lambda$ PP-Beträge als normale rote Blutkörperchen. Dies ist auch bei Zellen mit abnormal grossem Volumen der Fall. Als Folge der - was die Blutkörperchen betrifft-abnormalen Zusammensetzung des Bluts von Anämiepatienten können abnormale APP-Gehalto des Gesamtbluts vorkommen, die in keiner Beziehung zur Aneurinversorgung des Körpers stehen. Darum sollte mit jeder APP-Bestimmung im I3lut, die auf die Entdeckung eines eventuellen Aneurinmangels gerichtet ist, eine hämatologische Intersuchung verbunclen werden. Die APP-Bestimmung in den roten und weissen Blutkörperchen ist der Bestimmung im Gesamtblut vorzuziehen. Es werden Beispicle gegeben, bei denen dis Aufteten eine's Aneurinmangels durch Bestimmungen nach diesen Richtlinien bewiesen werden konnte.

\section{REFEIRENCES}

1 H. I. Mason and R. 1). Williams, J. Clin. Iniest., 2 I (I942) 247.

2 O. Mickelsen, W. O. Caster, and A. Keys, J. Biol. Chem., i 68 (1947) 415.

3 A. Keys, A. Henschel, H. I. Taylor, O. Mickelsen, and J. Brozek, Am. J. l'hysiol., 1. (1945) 5 .

4 IR. W. Wilkins, F. H. L. Taylor, and S. Weiss, Proc. Soc. Expll Biol. Med., 3.5 (1930-1937) 584.

5 Z. A. Yanof, Proc. Soc. Expll Biol. Med., 47 (I9+1) 5 I6.

6 J. I.ehmann and H. E. Niklsen, Nord. Med., I (I939) 289.

7 H. M. Sisclaik, Biochem.J., 33 (1939) 2027.

8 K. RitSERT, Klin. Wochschr., 18 (1939) 852.

- R. S. Goodhakt and H. M. Sinclaik, Biochem. J., 33 (1939) 1099.

$10 \mathrm{H}$. Wortis, R. S. Goonhart, and E. Bueding, Am. J. Diseases Children, oi (Ig.j I) 220.

11 S. DE Jong, Acta Brevia Neerland. Physiol. Pharmacol. Microbiol., I I (I94I) 176.

12 R. A. Benson, C. M. Witzberger, L. B. Siobody, and L. Lrwis, J. Pediat., 21 (1942) 659.

13 H. (a. K. Westrenbrink, F. P. Steyn Parvé, A. C. van dek linden, and W. A. van den Broek, Z. Vitaminforsch., I3 (I9.4) 218 .

16 T. E. Friedemanin and T. C. Kmieciak, J. Lab. Clin. Med., 28 (1943) I 262.

15 G. J. OOSTERHUIS, Thesis, Amsterdam, 1945.

18 H. O. Bang, Acta Med. Scand., 122 (1945) 38.

17 H. (;. Oldham, M. V. Davis, and I. J. Roberts, J. Nutrition, 32 (1946) I63.

18 M. LoDI, Z. Vitaminforsch., I 7 (1946) 36.

19 R. Goodhart and H. M. Sinclair, J. Biol. Chem., I.32 (I940) i I.

20 A. Г. (iorham, J. C. Abels, A. I. Robbins, and C. P. Rhoads, J. Clin. Invest., 21 (I942) I6I.

21 E. Florijn AND G. SMITs, Nederland. Tijdschr. Geneesk., 91 (1947) 3292.

22 K. A. FISHER, Statistical Methods for Research Workers, Ioth ed., London, 1948.

23 S. J. E. Pannekoek-Westenblrg axd A. (G. van Veen, Geneesk. Tijdschr. Nederland. Indië, 80 (I940) 1773 .

24 E. . . Rowlands and J. F. Wilkinsox, Brit. Med. J., 2 (1938) 878.

Received August $5^{\text {th }}$, I948 